\title{
Simple Defense of the Ontological as Argument
}

\author{
Brian Lang \\ University of Missouri
}

One of the standard criticisms of the ontological argument takes the form of a reductio ad absurdum. Rather than beginning with the idea of God, critics begin with the idea of a non-existent or contingent object. They then purport to argue mutatis mutandis to the absurd conclusion that the non-existent object exists or that the contingent object exists necessarily. I shall develop a dialectic between Descartes and several of his critics to illustrate (and rebut) various forms of this reductio. The essence of my defense is the claim that Descartes' argument for God's existence ranges over a limited set of ideas-a set that excludes those ideas traditionally used to formulate the reductio. Furthermore, if the Doctrine of Divine Property Simplicity is true (as Descartes believes that it is), then the set of ideas has only one member-the idea of God. And if this is the case then no reductio of this sort can ever work.

\section{Caterus' Lion}

In the First Set of Objections Caterus develops his version of the reductio by beginning with the idea of an "existent lion" (CSM II, 72). Like the idea of God, the idea of an "existent lion" necessarily has the property of existence. ${ }^{1}$ The parallel reasoning is supposed to run as follows:

Descartes

P1) I have an idea of God that necessarily has the property of existence.

C) God necessarily exists.
Caterus

P1) I have an idea of an "existent lion" that necessarily has the property of existence.

C) An existent lion necessarily exists. (false) 
Descartes can simply reply that Caterus has focused on the wrong modality, for there is a difference between an idea that necessarily involves contingent existence and an idea that necessarily involves necessary existence. Caterus' lion is the former, and Descartes' God is the latter. Therefore the reasoning is not parallel.

Descartes

P1) I have an idea of God that necessarily has the property of necessary existence.
Caterus

P1) I have an idea of an "existent lion" that necessarily has the property of contingent existence.

For this reason, Caterus' version of the reductio fails.

\section{Russell's Golden Mountain (Part I)}

Russell offers a more promising example in the form of the idea of an "existent golden mountain." His argument is superior to Caterus' insofar as Russell does not illicitly change modality.

Caterus

P1) I have an idea of an "existent lion" that necessarily has the property of contingent existence.

C) An "existent lion" necessarily exists.
Russell

P1) I have an idea of an "existent golden mountain" that necessarily has the property of contingent existence.

C) An "existent golden mountain" contingently exists. (false)

Therefore, Russell's reductio is a success if the Cartesian argument is an argument about the nature of existence.

Descartes

P1) I have an idea of God that necessarily has the property of necessary existence.
Russell

P1) I have an idea of an "existent golden mountain" that necessarily has the property of contingent existence. 

C) God necessarily exists.
C) An "existent golden mountain" exists. (false)

Perhaps the ontological argument is designed to demonstrate that ideas that entail existence (of whatever sort) necessitate that the objects of those ideas exist. Thus ideas that entail necessary existence (like God) necessarily exist, and ideas that entail contingent existence (like an "existent golden mountain") contingently exist. And since the latter is obviously false, Russell's reductio appears to succeed. It is my contention that the Cartesian argument is not an argument about the nature of existence-it is an argument about the nature of perfection. In order to see how this is the case we need to take a detour into the notion of "perfection."

\section{Perfection}

The standard definition of perfection has three features. Perfections constitute a subset of the class of great-making properties. A great-making property is a property that is intrinsically better to possess than to lack. So, for example, if it is intrinsically better to be in a certain state of knowledge $k$ than the corresponding state of ignorance $\sim k$, then being in state $k$ is a greatmaking property. Beings who have the property $k$ are "greater" than those who do not.

Properties, in general, can be divided into those that admit of degrees and those that do not. Properties that admit of degrees include quickness, sadness, healthiness, and reddishness. Properties that do not admit of degrees include being pregnant, being distinct from the number 7 , and having four sides. Furthermore, properties that admit of degrees can be divided into those that have a logical maximum and those that do not. For example, being reddish has the logical maximum of being red. Nothing is more reddish than an instance of the color red. In contrast, the property of length does not have a logical maximum. There is no longest possible length. These notions allow us to 
identify three individually necessary and jointly sufficient conditions for being a perfection. A perfection is a degreed greatmaking property with a logical maximum. ${ }^{2}$

\section{The Problem of Infinity}

Before we return to Russell's Golden Mountain, it is important to determine whether there is any reason to believe that Descartes is working under some other understanding of perfection. Descartes often refers to God's perfections as "infinite." This seems to be incompatible with the understanding of perfections as necessarily possessing logical maxima, for logical maxima entail finitude. However, in speaking about his own exemplification of the perfection of knowledge, Descartes makes the following claim:

\footnotetext{
"What is more, even if my knowledge always increases more and more, I recognize that it will never actually be infinite, since it will never reach the point where it is not capable of further increase; God, on the other hand, I take to be actually infinite, so that nothing can be added to his perfection" (CSM II, 32, emphasis mine).
}

This passage makes it clear that Descartes does not use the term "infinity" to identify a property without a logical maximum. He uses it in precisely the opposite manner-to identify a property that does have a logical maximum. Therefore, when Descartes claims that God has "infinite" knowledge and power, what he is asserting is that God possesses the logically maximal amount of both knowledge and power. Descartes also tends to refer to infinite perfections as "supreme." So, for example, whereas Descartes exemplifies merely the "perfection" of power, God exemplifies the "supreme perfection" of omnipotence. This will become an important distinction, for much hangs on the difference between a less-than-maximal exemplification of some perfection and a maximal exemplification thereof. 
Let us briefly review the issue that led to our examination of perfection. Russell's version of the reductio moves from the idea of a contingent golden mountain to its contingent existence in precisely the same manner that the ontological argument moves from the idea of a necessarily existent God to His necessary existence. Unlike Caterus Russell does not illicitly change modality. Thus, Russell's reductio is a success if the Cartesian argument is an argument about the nature of existence. But it is my contention that it is not. Instead it is an argument about the nature of perfection.

This claim is borne out by Descartes' answer to Caterus in the First Reply to Objections. It is here that Descartes argues for God's necessary existence, based not on a premise involving existence but on the premise that we have a clear and distinct idea of an omnipotent being. That is to say that he argues from the supreme perfection of omnipotence to the supreme perfection of necessary existence. This demonstrates that the set of ideas over which the ontological argument ranges is not the set of ideas involving existence; it is the set of ideas involving supreme (i.e. maximally exemplified) perfection. Neither Caterus' lion nor Russell's golden mountain exemplify any supreme perfections. For this reason Descartes' argument simply does not apply to them.

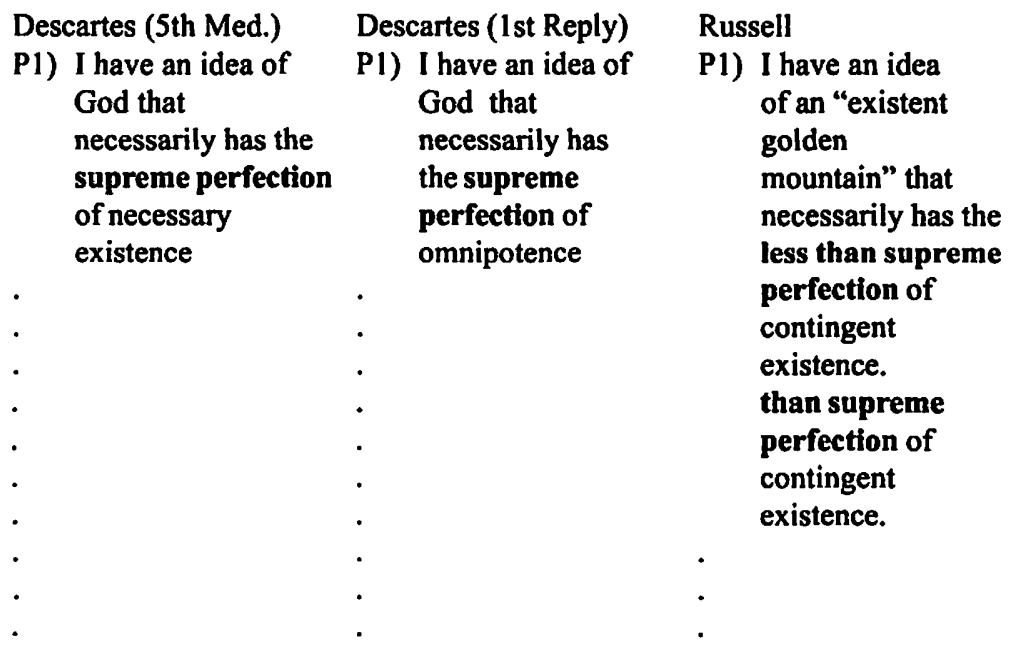



C) A supremely
perfect being
C) A supremely
perfect being
C) A less than
perfect mountain
necessarily exists.
necessarily exists. contingently exists.

Descartes' argument only warrants arguing from an idea possessing some supreme perfection (omnipotence, omniscience, impeccability, etc.) to an instance of that idea possessing the supreme perfection of necessary existence. Therefore, in order for a reductio of this sort to work, one must begin with an idea that entails some supreme perfection or another-the idea of an omnipotent being or the idea of an omniscient being, etc. Existent lions and golden mountains will not suffice.

\section{A Perfect Island}

There remains one final version of the reductio worthy of our consideration. Some critics have suggested that the Cartesian argument for God's existence can also be used to prove the existence of a supremely perfect island. This version takes into account the fact that the Cartesian argument is about the nature of perfection rather than existence. Perhaps if we have the idea of a supremely perfect island, its very perfection entails its necessary existence. For how could I, an imperfect being, have originated such a perfect idea of a tropical paradise? It must exist in order to explain my possession of the idea.

In order to make this argument precisely analogous it helps to specify exactly what "supreme perfection" the island possesses. Presumably, the perfection in question is beauty. ${ }^{3}$ We can thereby formulate the following successful version of the reductio:

Descartes (1st Reply)

P1) I have an idea of a supremely perfect being (God) that exemplifies the supreme perfection of omnipotence.

C) A supremely perfect being necessarily exists.
The Perfectly Beautiful Island

P1) I have an idea of a supremely perfect island that exemplifies the supreme perfection of maximal beauty.

C) A supremely perfect island necessarily exists. 


\section{A Simple Defense}

This would be the end of the matter if not for Descartes' commitment to the traditional theistic Doctrine of Divine Property Simplicity. ${ }^{4}$ In the Third Meditation Descartes affirms his belief in the simplicity of God's "attributes":

\footnotetext{
"The unity, the simplicity, or the inseparability of all the attributes of God is one of the most important of the perfections which I understand him to have" (CSM II, 34).
}

Now there seem to me to be two possible meanings of the word "attributes." On one hand, God's "attributes" might be nothing more than His properties. On the other, God's "attributes" might be restricted to some subset of divine properties unique to Him such as His "supreme perfections" (as exemplified in Descartes' frequent lists of divine attributes-omnipotence, omniscience, etc.). The first meaning is indefensible (although that does not mean Descartes was not committed to it). For the Doctrine of Divine Property Simplicity is the claim that some of God's properties are metaphysically indistinguishable. This claim cannot be true about all of God's properties (where the term property is broadly construed), for some of God's properties are unique to Him (i.e. aseity) and others are shared with other things (i.e. knowing the name of the author of this essay). But if all of God's properties are united in a simple whole that does not admit of distinctions, then there is no difference between aseity and knowing my name. Aside from the incredible counter-intuitiveness of this claim, it implies that anyone who knows my name is also the creator of everything distinct from himself or herself (and this is patently false).

The upshot is that in order for the Doctrine of Divine Property Simplicity to be defensible, it must range over a set of properties unique to God. As noted earlier, in the First Reply to Objections Descartes argues from God's omnipotence to his necessary existence. This makes sense once one recognizes Descartes' commitment to divine property simplicity. For God's properties are not diverse-they are simple. Thus they are all identical to each other and to God Himself. So God $=$ Omnipotence $=$ 
Omniscience $=$ Necessary Existence and so on. Given this traditional theistic conception of God, it becomes clear Descartes' argument from Omnipotence to Necessary Existence is merely a particular implication of Divine Simplicity. He could have argued from any of God's unique, simple attributes to any other attribute. For example, the fact that I have an idea of an impeccable being entails that this impeccable being exists (maximal goodness to necessary existence). And the fact that I have an idea of an omniscient being entails that I have an idea of an omnipotent being.

This applies to the Ontological Argument because necessary existence is part of the simple unity of God. Thus the Ontological Argument can be used to argue from our "idea" of any of the simple divine attributes. And this has the added implication that the Ontological Argument is not an argument about existence (as Russell thought) or even about perfection (as friends of the Perfect Island think). It is instead an argument that ranges over the set of God's attributes that are united in a simple whole-a set that, strictly speaking, has only one member-despite appearances to the contrary.

\section{Classical Theism}

P1) I have idea of a supremely perfect being that exemplifies one property that is unique to itself and to which it is identical. This property can be described as "omnipotence," "necessary existence,"s "omniscience," etc.

C) A supremely perfect being necessarily exists.

Therefore, if the Doctrine of Divine Property Simplicity is true, then no reductio of the sort proposed will ever work. For the argumentation in the Ontological Argument simply does not apply to anything outside of God and thus cannot be used to argue for the existence of other contingent or non-existent entities. 


\section{Notes}

'For good or ill, Descartes and some of his critics predicate existence to individuals. Although this practice is generally considered improper it has some notable defenders including P.T. Geach, "What Actually Exists," Proceedings of the Aristotelian Society, supp. vol. 42 (1968): 7-16. Reprinted in God and the Soul (London: Routledge and Kegan Paul, 1969), chap. 5., J.L. Mackie, "The Riddle of Existence," Proceedings of the Aristotelian Society, supp. vol. 50 (1976): 247-67; and G. Evans, The Varieties of Reference (Oxford: Oxford University Press, 1982), chap. 10. For an excellent general overview of the issue and defense of a position much like Descartes' see B. Miller, The Fullness of Being: A New Paradigm for Existence, Notre Dame, IN: University of Notre Dame Press, 2002.

${ }^{2}$ For an interesting defense of the existence of such maxima see William Mann, "The Divine Attributes," American Philosophy Quarterly. 1975, pg. 151-159. For a rather less compelling denial of their existence see Morris Lazerowitz, "On a Property of a Perfect Being"; Mind, 1983, pg. 257-263.

${ }^{3}$ This raises the question as to whether or not beauty has a logical maximum. But regardless of whether it does or not, a similar argument can be formulated involving a "supremely perfect scholar" who is omniscient (or some other non-existent entity that exemplifies a standard supreme perfection).

${ }^{4}$ There has been a recent surge of interest in this doctrine. Contemporary defenders of divine simplicity include Brian Leftow, "Is God an Abstract Object?" Nous, XXIV, 4 (1990); William Mann, "Divine Simplicity," Religious Studies XVIII (1982); "Simplicity and Immutability in God," International Philosophical Quarterly, XXIII (1983); and "Simplicity and Properties: A Reply to Morris," Religious Studies, XXII (1986); Katherin Rogers, "The Traditional Doctrine of Divine Simplicity," Religious Studies, XXXII (1996); Stump \& Kretzmann, “Absolute Simplicity," Faith and Philosophy, II (1985); and William Valicella, "Divine Simplicity: A New Defense," Faith and Philosophy, IX (1992). Recent critics include Richard LaCroix, "Augustine on the Simplicity of God," The New Scholasticism, LI, 4, (1977); Alvin Plantinga, Does God Have a Nature? (Milwaukee: Marquette University Press, 1980); Morris, "On God and Mann: A View of Divine Simplicity," in Anselmian Explorations (Notre Dame, IN: University of Notre Dame Press, 1987); and Christopher Hughes, On a Complex Theory of a Simple God (Ithaca, NY: Cornell University Press, 1989). 
${ }^{5}$ I argue elsewhere (unpublished manuscript-“God's Uniquely Iterated Existence") that God's necessary existence is unique insofar as it is logically prior to the necessary existence of everything else, including propositions, mathematical truths, and the like. 